\title{
Moninaisuudelle tilaa - työnohjaus kulttuurienvälisen osaamisen edistäjänä
}

\author{
Aila Niemelä
}

\section{Kulttuurisesti monimuotoistuva työelämä}

Lähes jokainen työelämän ajankohtainen julkaisu alkaa muutokseen liittyvällä ajatuksella. Murrokseen sisältyy myös nopeasti tapahtunut kulttuurinen monimuotoistuminen. Ei ole kyse vain yksittäisistä muuttovirroista vaan superdiversiteetistä, globaalin maailman yhdestä pysyvästä tunnusmerkistä, yhdestä uudesta normaalista. Kun viitataan tulevaisuuden työtaitoihin, niissä on mukana kulttuurienväliseen osaamiseen ja diversiteettiin liittyvä ulottuvuus. (Hanhinen 2010; Noble ym. 2016.)

Työelämässä kulttuurista monimuotoisuutta lähestytään edelleen usein empivästi ja enemmän emotionaalisesti kuin esimerkiksi ongelmanratkaisun näkökulmasta. Siihen liittyy paljon epätietoisuutta ja tiedon puutetta. Helposti rajataan ja erotetaan enemmän kuin yhdistetään ja tasapainotetaan. Puheen sävyt liikkuvat usein joko myötätunnon tai uhkakuvien kysymyksissä, eikä omaa ajattelua kyseenalaisteta eikä jäsennetä. Myös käsitteellistäminen ja tutkimus painottuvat ulkomaalaistaustaisiin ihmisiin identiteetin, työolosuhteiden, sopeutumisen tai tukemisen näkökulmista.

Yllättävän vähän on avattu esimerkiksi sitä, mitä kulttuurienvälisellä osaamisella tarkoitetaan (Dervin \& Keihäs 2013). Se oli pitkään kielitieteilijöiden ja viestinnän aluetta ja alkoi sitten pikkuhiljaa rantautua koulutuksen maailmaan kansainvälisyyskasvatuksena.
Korostettiin toisten kulttuurien tuntemista ja yleisiä kommunikaatiotaitoja. Usein laajemmat ja kokonaisvaltaisemmat näköalat puuttuivat. Työelämässä vieraisiin kulttuureihin on suhtauduttu varovaisesti ja pelonsekaisestikin. Kulttuuriin liittyvä tiedon rakentaminen, käsitteiden avaaminen, erilaistaminen ja ongelmanratkaisu ovat kuitenkin entistä keskeisempiä esimerkiksi asiakaspalvelu- ja ohjaustyössä tai erilaisissa oppimis- ja toimintaympäristöissä. Siksi ammatilliseen osaamiseen on syytä kiinnittää tietoista, kriittistä ja ajanmukaista huomiota. (Puukari \& Korhonen 2013; Wallin 2013.)

Tarkastelin väitöskirjassani, millaisia oppimisen tarpeita uudistuva ja kulttuurisesti monimuotoistuva työelämä ja asiakastyö tuovat mukanaan, millaista ammattitaitoa ne edellyttävät ja miten oppimista voidaan tukea. Jäsensin kulttuuriseen monimuotoisuuteen liittyvää ammatillista osaamista käsitteillä monikulttuuriosaaminen ja monikulttuurikompetenssi. Työelämäosaaminen muodostaa kehyksen professionaalisen kasvun edistämiselle. Etsin liittymäkohtia työelämäosaamisen, henkilöstön kehittämisen ja ohjausmenetelmien välille. (Hanhinen 2010; Pylväs 2018; Vehviläinen 2014; Wallin 2013.)

Tutkimukseni fokus oli yhdessä ohjauksen ja konsultatiivisen työn menetelmässä, työnohjauksessa. Oli kiinnostavaa tarkastella, soveltuuko se monikulttuuriosaamisen vahvistamiseen työelämän oppimistilana ja -alustana. 
Tarkastelin työnohjausta koulutuksellisena, henkilöstön kehittämiseen tähtäävänä menetelmänä, jolla tavoitellaan uutta perspektiiviä, systeemistä ymmärrystä, ammatillista kasvua, toimivaa vuorovaikutusta, hyvinvointia työssä ja jaettua oppimista työprosessien kehittämiseksi sekä yksilö- että yhteisötasolla. Työnohjaus näyttäytyy dialogisena ja reflektiivisenä, pitkäkestoisena prosessina, jossa yhdistyvät kohtaaminen ja voimautuminen sekä oman tai yhteisön työn tutkiminen ja kehittäminen onnistumisineen ja ongelmakohtineen. Halusin löytää näkökulmia myös työnohjauksen uudistumiseen.

Metodisesti tutkimus perustui refleksiiviseen ja kerronnalliseen lähestymistapaan. Tutkimuskysymysten taustalla oli kolme ulottuvuutta: työnohjausprosessi, ohjattavassa havaittava muutos sekä työnohjaajan oma osaaminen. Halusin selvittää, miten kulttuuriseen monimuotoisuuteen liittyviä kysymyksiä otetaan esiin ja käsitellään työnohjauskeskusteluissa, millaisia muutoksia työnohjauksella saadaan aikaan ja millaisia työnohjaajien omat monikulttuuriset valmiudet ovat. Keräsin aineistoa kolmella tavalla: systemaattisella kirjallisuuskatsauksella sekä asiantuntijoiden syvähaastatteluilla ja työnohjaajien fokusryhmäkeskustelussa sosiaalisessa mediassa. Aineiston käsittelyssä hyödynsin ja sovelsin sekä odotus- että sisällönanalyysia.

\section{Kulttuurienvälinen osaaminen työssä}

Kulttuurinen monimuotoisuus tuo työyhteisössä usein esiin tilanteita, joissa etsitään välineitä avoimeen keskusteluun sekä tasapainoiseen ja tasapuoliseen yhteistoimintaan. Pelkkä hyvä tahto tai edes yhteinen arvopohja ja kunnioitus eivät aina riitä. Erityisesti esimiestyössä, koulutuksessa ja työyhteisöjen kehittämisessä kaivataan diversiteetin ja kulttuurisen kontekstin teoreettista jäsennystä mutta myös käytännön monikulttuuriosaamista.

Monikulttuuriosaamisen yksi tärkeä näkökulma on kulttuurin sekä persoonallisten sy- vien ja piilossa olevien kerrostumien vaikutus siihen, miten ihmiset suhtautuvat kulttuuriseen koodistoon, muutokseen ja oppimiseen toimintaympäristössään (Shaules 2007). Kulttuurin vaikutusta ei ole helppo havaita toisissa eikä varsinkaan itsessään. Kuitenkin sekä omalla että vieraalla kulttuurilla on merkittävä rooli vuorovaikutuksessa (Puukari \& Korhonen 2013). Muun muassa Rathje (2014) ja Rosinski (2003) tuovat varsin radikaalisti niin kansainvälisen kaupan ja johtamisen kuin koulutuksen ja valmentamisenkin keskusteluun väitteen, että monikulttuuriosaaminen ei ole informaatiota kulttuurien erilaisista piirteistä, kuten yhä usein ajatellaan. Se ei ole myöskään tarkkoja ohjeita vaan tilannetajua, joka auttaa löytämään toimivia ratkaisuja erilaissa tilanteissa. Monikulttuuriosaaminen on ensisijaisesti omien ajatusmallien työstämistä ja muutosta.

Käsitteellisesti monikulttuuriosaaminen tiivistyy työssä tarpeelliseksi työelämäkvalifikaatioksi ja ammatilliseksi kompetenssiksi, joiden inklusiivisia elementtejä ovat vuorovaikutus kulttuurisesti monimuotoisessa toimintaympäristössä, yleiset ja erityiset sosiaaliset taidot sekä kulttuurinen kontekstuaalinen ja ilmiötason ymmärrys (Hanhinen 2010; Wallin 2013). Muun muassa Pylvään (2018) mukaan kompetenssiprosessissa olennaista on kyky omien emootioiden, motiivien, asenteiden ja toiminnan kriittiseen reflektioon.

Kulttuurienvälinen yhteistoiminta työelämässä edellyttää siis rationaalisen ajattelun lisäksi reflektiivisyyttä. Mielenkiintoista onkin, miten vähän kiinnitämme huomioita omiin kulttuurisiin työelämätaitoihimme. Pidämme niitä ehkä itsestäänselvyyksinä - pelkäämme oman ajattelumme tutkimista, ulkoistamme kulttuuria. Kulttuurien erilaisuus ei kosketa meitä tai emme pidä sitä olennaisena. Kulttuuriset kysymykset eivät ole kuitenkaan vain yksilöllisiä, työntekijöiden itsensä tai lähijohdon ratkaistavissa olevia, vaan koko työyhteisön yhteisiä ja organisaation kehittymiseen ja kehittämiseen liittyviä haasteita. Siksi kyse on oppimisen prosessista, ei opinkappaleesta. 
Saattaa olla, että työyhteisössä on aloitettava kysymällä, mistä oikeastaan puhumme, kun puhumme kulttuurista. Mikä toiminnassamme on universaalia, mikä opittua, mikä perustuu yksilöllisiin ominaisuuksiin? Milloin kulttuuri tulee huomioida, milloin jättää huomiotta? Usein on kyse johtamiseen liittyvistä pulmista, joihin ei kyetä löytämään ratkaisuja, koska avointa keskustelua ei käydä. Monimutkaisuuden, uskomusten, kommunikaatiovaikeuksien ja jännitteiden kanssa on opeteltava tulemaan toimeen, vaikka niitä ei täysin pystyttäisikään hallitsemaan tai selittämään. Ne eivät ole mielipidekysymyksiä vaan faktoja työn arjessa. Niiden avaaminen yhdessä voi käynnistää aivan uusia näköaloja ja toimintamalleja. (Falender ym. 2014; Keisala 2012.)

Työyhteisössä voidaan joko tyytyä tilanteeseen tai yrittää pikkuhiljaa oppia yrityksen ja erehdyksen kautta - tai ottaa proaktiivisempi ote. Muodollinen koulutus vastaa vain osittain tähän tarpeeseen. Tarvitaan myös epämuodollisia koulutusinterventioita ja vaikuttavia välineitä itseohjautuvaan osaamisen sekä toimintaympäristön ja keskustelukulttuurin kehittämiseen. Tutkimukseni keskiössä ollut työnohjaus, jossa keskitytään jäsentämään toimijuutta sekä tutkimaan yhdessä omaa osaamista parempaan tulokseen ja hyvinvointiin pääsemiseksi, on esimerkki tällaisesta interventiosta. Kulttuurisella monimuotoisuudella on työnohjauksessa kaksi ulottuvuutta. On työnohjausta työyhteisöissä, joissa henkilöstö edustaa erilaisia etnisiä tai kulttuurisia taustoja, sekä työnohjausta, jossa ohjattavat työskentelevät ulkomaalaistaustaisten alaisten tai asiakkaiden kanssa.

\section{Kulttuurinen monimuotoisuus työnohjauksessa}

Tutkimustulosteni keskeisin viesti on, että kulttuurinen monimuotoisuus ja siihen liittyvät kysymykset eivät ole helppoja eivätkä itsestään- selvyyksiä työelämän arjessa. Siksi on käytännössä usein yksinkertaisempaa sivuuttaa ne kuin käydä niihin käsiksi. Näin tapahtuu myös työnohjauksessa. Ainakaan kansainväliseen tutkimukseen peilaten tämä ei ole yllätys.

Haastateltavieni kokemus oli, että työnohjaus antaa joka tapauksessa mahdollisuuden ja tilaa moninaisuuden jäsentämiseen, käsitteiden avaamiseen ja erilaisuuden hyväksymiseen. Työnohjauksen suoraa vaikutusta mahdolliseen muutokseen on vaikea todentaa. Selkeällä tavoitteenasettelulla voidaan silti arvioida työnohjauksen merkitystä ohjattaville ja heidän yhteisölleen.

Väitöstutkimukseni tulokset vahvistavat sen, mikä myös on ollut tiedossa jo pitkään: työnohjaus on edelleen paljolti työnohjaajan näköistä. Mitä selkeämpi, monipuolisempi tai varmempi orientaatio työnohjaajalla on kulttuuriseen kontekstiin, sitä avoimemmin siihen liittyviä kysymyksiä voidaan työnohjauksessa käsitellä ja päästä toimiviin ratkaisuihin työpaikoilla. Ilman monikulttuurikompetenssia on vaikea vaikuttaa ohjattavienkaan oppimiseen. Kulttuurinen monimuotoisuus haastaa siis myös työnohjauksen ja hyvin koulutetut työnohjaajat. Työnohjaajatkin näyttävät tarvitsevan oman monikulttuuriosaamisensa vahvistamista: sekä rohkeutta ottaa puheeksi että teoreettista ymmärrystä. Ammatillisen ja täydennyskoulutuksen näkökulmasta tämä on tärkeä tieto.

Tutkimukseni kiteytyy ajatukseen, että sekä ohjattavat että työnohjaajat näyttävät olevan monikulttuurisissa kysymyksissä hieman varpaillaan. Työnohjaus on kuitenkin hyvä paikka oppia ymmärtämään erilaisuutta. Perustaitojen hallinnan lisäksi työnohjaajan itsensäkin on tärkeää uudistua jatkuvasti. Kulttuurinen monimuotoisuus on otettava entistä tietoisemmaksi tavoitteeksi niin työnohjauksessa kuin työnohjaajien koulutuksessa ja valmennuksessakin. 


\section{Työnohjauksen potentiaali työelämäosaamisessa}

Yksi tutkimukseni päätelmistä on, että työnohjauksella on henkilöstön ja työyhteisöjen kehittämisessä vielä hyödyntämätöntä käyttövoimaa. Sen mahdollisuudet ovat paitsi työhyvinvoinnin, johtamisen, osaamisen, jakamisen ja sosiaalisen pääoman lisäämisessä myös transformatiivisuutta ja resilienssiä edellyttävissä muutostilanteissa.

Työyhteisöjen nopea monimuotoistuminen tuo kulttuureihin ja niiden erilaisuuteen liittyvät kysymykset keskusteluun, joko näkyvästi tai näkymättömästi. Se asettaa muutoshaasteita henkilöstön kehittämiseen ja työelämäosaamiseen liittyvälle diskurssille. Onnistuessaan yhteisöllinen työskentely voi heijastua myös yhteiskunnallisesti - se voi vahvistaa integraatiota ja edistää pyrkimystä parempaan työelämään. Sitä kannattaa kaikin keinoin vaalia kehittämällä edelleen työssä oppimista tukevia ohjattuja ja itseohjautuvia keinoja. (Hytönen 2007; Hyytinen 2017; Pylväs 2018.)

Työnohjauksen menetelmänä on elettävä ajassa ja työelämän liikkeessä. Noblen ja kump- panien (2016) mukaan sitä on tarkasteltava tutkitun tiedon valossa ja kriittisesti sekä kehitettävä työelämän muutostarpeiden mukaisesti. Edellä mainitut tutkijat ennustavat, että työnohjaus ottaa entistä aktiivisemman ja dynaamisemman roolin työyhteisön muutos-, oppimis- ja kehittymisprosesseissa. Samalla on säilytettävä se työnohjauksen traditionaalinen kohtaamisen ydin ja erityisyys, mikä tuottaa lisäarvoa työelämään, toimijuuteen ja työyhteisöihin.

Aila Niemelän kasvatustieteiden väitöskirja Työnohjaus monikulttuuriosaamisen edistäjänä tarkastettiin Tampereen yliopistossa 15.8.2019. Teos löytyy sähköisessä muodossa osoitteesta https://trepo.tuni.fi//handle/10024/116280

\section{Kirjoittaja}

Aila Niemelä, KT, organisaatiokonsultti, työnohjaaja,

Awailable Consulting, sähköposti: aila.niemela@awailable.com twitter: @AilaNiemela

\section{Kirjallisuus}

Dervin, F. \& Keihäs, L. (2013) Johdanto uuteen kulttuurienväliseen viestintään ja kasvatukseen. Joensuu: Suomen kasvatustieteellinen seura.

Falender, C., Shafranske, E. \& Falicov, C. (2014) Multiculturalism and diversity in clinical supervision: A competency-based approach. Washington: APA.

Hanhinen, T. (2010) Työelämäosaaminen: Kvalifikaatioiden luokitusjärjestelmän konstruointi. Acta Electronica Universitatis Tamperensis 1021. Tampere: Tampere University Press.

Hytönen, T. (2007) Henkilöstön kehittäminen aikuiskasvatuksen työkenttänä. Teoksessa K. Collin \& S. Paloniemi (toim.) Aikuiskasvatus tieteenä ja toimintakenttinä. Jyväskylä: PS-kustannus, 189-220.

Hyytinen, K. (2017) Supporting service innovation via evaluation: A future oriented, systemic and multi-actor approach. DOCTORAL DISSERTATIONS 14/2017, VTT Science 146. Helsinki: Aalto University.

Keisala, K. (2012) Monikulttuurisen työyhteisön viestintä. Tampere: Tampere University Press.

Noble, C., Gray, M. \& Johnston, L. (2016) Critical supervision for the human services: A social model to promote learning and value-based practice. Lontoo: Jessica Kingsley Publisher.

Puukari, S. \& Korhonen, V. (2013) Monikulttuurinen ohjaus- ja neuvontatyö. Jyväskylä: PS-kustannus. Pylväs, L. (2018) Development of vocational expertise and excellence in formal and informal learning environments. Acta Universitatis Tamperensis 2353. Tampere: Tampere University Press.

Rathje, S. (2014) Multikollektivität: Schlüsselbegriff der modernen Kulturwissenschaften. Teok- 
sessa Kultur und Kollektiv: Festschrift für Klaus P. Hansen, 39-59.

Rosinski, P. (2003) Coaching across cultures: New tools for leveraging national, corporate \& professional differences. New York: Nicholas Brealey Publishing.

Rosinski, P. (2010) Global coaching: An integrated approach for long-lasting results. New York: Nicholas Brealey Publishing.
Shaules, J. (2007) Deep culture: The hidden challenges of global living. Clevedon: Multilingual Matters.

Vehviläinen, S. (2014) Ohjaustyön opas: Yhteistyössä kohti toimijuutta. Helsinki: Gaudeamus.

Wallin, A. (2013) Monikulttuuriosaaminen - uudistuvan työyhteisön valttikortti. Helsinki: Klaava Media. 